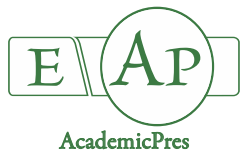

\title{
Phenolic Profiles, Antimicrobial and Cytotoxic Properties of Both Micropropagated and Naturally Growing Plantlets of Calamintha sylvatica subsp. sylvatica Bromf.
}

\author{
Mustafa CÜCE ${ }^{1 *}$, Tuba BEKİRCAN ${ }^{2}$, Abdul Hafeez LAGHARİ ${ }^{3}$, \\ Münevver SÖKMEN ${ }^{4,8}$, Atalay SÖKMEN ${ }^{5,8}$, Evren ÖNAY UÇAR ${ }^{6}$, \\ Ali Osman KILIÇ \\ ${ }^{1}$ Giresun University, Şebinkarahisar School of Applied Sciences, Department of Food Technology, 28400, Giresun, \\ Turkey; mustafacuce@windowslive.com ("correspondingauthor);mustafacuce@windowslive.com \\ ${ }^{2}$ Eurasia University, Faculty of Science and Art, Department of Biochemistry, 61080, Trabzon, Turkey; tubabekircan@gmail.com \\ ${ }^{3}$ Karadeniz Technical University, Faculty of Science, Department of Chemistry, 61080 Trabzon, Turkey; hafeezlaghari58@yahoo.com \\ ${ }^{4}$ Konya Food and Agriculture University, Faculty of Engineering, Department of Bioengineering, 42080 Konya, \\ Turkey; munevver.sokmen@gidatarim.edu.tr \\ ${ }^{5}$ Konya Food and Agriculture University, Faculty of Agriculture and Natural Sciences, Department of Plant Production \& Technologies, 42080 \\ Konya Turkey; atalay.sokmen@gidatarim.edu.tr \\ 'I Istanbul University, Faculty of Science, Department of Molecular Biology and Genetic, 34134 Istanbul, Turkey; evrenonay@istanbul.edu.tr \\ ${ }^{7}$ Karadeniz Technical University, Faculty of Medicine, Department of Medical Microbiology, 61080 Trabzon, Turkey; akilic@ktu.edu.tr \\ ${ }^{8}$ King Saud University, College of Science, Department of Zoology, 11451, Riyadh, Saudi Arabia
}

\begin{abstract}
A rapid micropropagation protocol was designed to produce Calamintha sylvatica plantlets by using nodal segments as explants for the shoot formation. 6-BA favored the highest shoot formation and biomass yield, whilst kinetin was found superior for the highest shoot length $(38.97 \pm 2.85 \mathrm{~mm})$ and node numbers $(2.89 \pm 0.63)$. Rosmarinic acid was detected as major phenolic acid, ranging from $7.59 \mathrm{mg} / 100 \mathrm{~g}$ to $81.44 \mathrm{mg} / 100 \mathrm{~g}$. Hexane extracts from natural and in vitro propagated plantlets showed activity only against Staphylococcus aureus ATCC 25923 with MIC values at 6.25 and $3.33 \mathrm{~m} / \mathrm{mL}$, respectively while in the latter case, extracts from natural plantlets exerted higher cytotoxic activity than those of micropropagated ones ( $\mathrm{IC}_{50}$ values were $83 \mu \mathrm{g} / \mathrm{mL}$ and $98 \mu \mathrm{g} / \mathrm{mL}$ on HeLa cells, respectively). C. sylvatica showed high micropropagation performance and produced remarkable amount of rosmarinic acid in vitro as well as antimicrobial and cytotoxic effect.
\end{abstract}

Keywords: antimicrobial activity; Calamintha sylvatica; cytotoxic activity; micropropagation; rosmarinic acid

\section{Introduction}

Calamintha sylvatica, commonly known as calamint, is an herbaceous cosmopolitan plant of the Lamiaceae family. This family is represented by 45 genus, 565 species and 735 taxa in the Turkish flora, whilst the Calamintha genus represented by 9 species and 12 taxa and five of them endemic. They are known as medicinal plants and used in the pharmaceutical industry and traditional medicine (Cunningham, 1993; De Silva, 1997) to perform in many treatments like diaphoretic, antispasmodic, antiseptic, expectorant, digestive, and for strengthening the central nervous system (Bown, 1995; Baytop, 1999; Malik et al., 2016). In addition, these plants are also commonly used as spices in food, and as fragrance in perfumery and cosmetics (Baytop, 1983, 1997).

In vitro propagation of aromatic plants has been considered as an alternative approach for rapid and large quantity production of plant materials and avoiding the damage and the extinction from their natural fields (Debnath et al., 2006; Lucchesini and Mensuali-Sodi, 2010; Ruffoni et al., 2010; Cüce et al., 2017). This approach has been proven for the production of bioactive secondary 
1146

metabolites of aromatic plants (Arikat et al., 2004; Pistelli Arikat et al., 2010). Recently, there has been a substantial effort towards the replacement of toxic bioactive compounds like butylated hydroxytoluene (BHT), butylated hydroxyanisole (BHA) with common plant phenolics as safer substitutes of antioxidant food additives. Among these, rosmarinic acid can be considered as a reliable candidate, since being used not only as antioxidant, but other biological activities such as inhibition of the attachment of herpes simplex virus 1 (Astani et al., 2012), anti-HIV (Louvel et al., 2013), and anti-inflammatory properties are also notable (Parnham and Kesselring, 1985). Since the organic synthesis of rosmarinic acid is difficult (Luis et al., 2013), isolation and increased production from different sources using new approaches and techniques has been the main focus of the current reports (Wüst Zibetti et al., 2013; Doring and Petersen, 2014; Zhu et al., 2014). The essential oils isolated from Calamintha species have been well-documented elsewhere (Alan et al., 2011; Formisanoa et al., 2014). However, no attempt has yet been made on its phenolics production capacity from the plantlets propagated in vitro. Moreover, rosmarinic acid content, as reported elsewhere, was available for $C$. grandiflora (Dobravalskyte et al., 2012), whereas phenolics content of micropropagated Calamintha plantlets has yet to be investigated. This study was planned to determine an influential procedure for the micropropagation of the seedlings of $C$. sylvatica from nodal segments and analyze their phenolics contents, rosmarinic acid, and finally, evaluate their antimicrobial and cytotoxic activities with the extracts of natural and micropropagated plantlets.

\section{Materials and Methods}

\section{Plantmaterial}

C. sylvatica seeds were collected between October and November in 2013 from Trabzon, Turkey, where it is a native plant, and stored in darkness at $4{ }^{\circ} \mathrm{C}$ until use. Before surface sterilization, seeds were incubated with $5 \%$ sucrose solution for $12 \mathrm{~h}$ supplemented with a few drops of commercial bleach (Domestos). After the solution was removed, and then surface was disinfected with $36.5 \%$ (v/v) hydrogen peroxide solution $\left(\mathrm{H}_{2} \mathrm{O}_{2}\right)$ for $30 \mathrm{~min}$. Disinfected seeds were cultured on approximately $30 \mathrm{~mL}$ nutrient basal media in $98.5 \times 59 \mathrm{~mm}$ glass containers (Magenta B-cap) for germination. Cultured seeds were kept in dark until the beginning of germination.

\section{Experimental}

Seed germination

MS (Murashige and Skoog, 1962) and Gamborg's B-5 (B5) (Gamborg et al., 1968) as cytokinin free, half strength (HS) and full strength (FS) each supported with $1.0 \mathrm{mg} \mathrm{l}^{-1}$ 6-benzyladenine (6-BA) were used for determining the best basal medium for seed germination. After 30 days of incubation, the percentage of germination and shoot length were calculated for each treatment.

Shoot proliferation

Nodal segments were gotten from the shoots of seedlings and placed on MS basal media containing 2\% (w/v) sucrose (Duchefa), 0.8\% (w/v) phyto agar (Duchefa) supplemented with different plant growth regulators (PGRs) including 6-BA, Kinetin (KIN), 2iP and TDZ (2.0 $\mathrm{mg} \mathrm{l}^{-1}$, each $)$ in combination with $\operatorname{IBA}\left(0.1 \mathrm{mg} \mathrm{l}^{-1}\right)$. All plant growth regulators used in this study were filter-sterilized with $0.22 \mu \mathrm{m}$ filters and added to the cooled media after autoclaving. The $\mathrm{pH}$ of the media was adjusted to 5.8 with 1 $\mathrm{N} \mathrm{HCl}$ or $1 \mathrm{~N} \mathrm{NaOH}$ before autoclaving. All cultures were preserved at $24 \pm 2{ }^{\circ} \mathrm{C}$ under a $16 \mathrm{~h}$ photoperiod at a photosynthetic flux of $50 \mu \mathrm{mol} \mathrm{m} \mathrm{m}^{-2} \mathrm{~s}^{-1}$, provided by cool daylight fluorescent lamps. After culturing a month, the proliferation was assessed by evaluating the number of micro shoots, length of shoots, and number of nods, and biomass yield based on fresh and dry weight.

\section{Extraction}

Samples of in vitro grown biomass were extracted as reported elsewhere (Kim et al., 2006; Ma et al., 2009). Briefly, $200 \mathrm{mg}$ of each sample was macerated in hexane (HE) and dichloromethane (DCM) (10 mL each) for 10 min, solvent was filtered out and residue was removed for in methanol extraction via same process for $30 \mathrm{~min}$. and methanol was evaporated in vacuo. The obtained methanol extract was then dipped in $\mathrm{pH} 2.0 \pm 0.1$ water and shaken vigorously followed by extraction with diethyl ether and ethyl acetate $(3 \times 5 \mathrm{~mL}$ each). Organic phases were combined, evaporated and made up in methanol $(\mathrm{MeOH})$ $(2.0 \mathrm{~mL})$ for HPLC analysis after passing through $0.45 \mu \mathrm{m}$ filter.

\section{Antimicrobial activity \\ Bacterial strains}

The HE, DCM and $\mathrm{MeOH}$ extracts were tested against Staphylococcus aureus ATCC 25923, Escherichia coli ATCC 25922, Pseudomonas aeruginosa ATCC 27853, Acinetobacter haemolyticus ATCC 19002, Enterobacter aerogenes ATCC 13048, Klebsiella pneumoniae ATCC 13883, Salmonella typhimurium ATCC 10708 for antibacterial activity and Candida albicans ATCC 10231, Candida parapsilosis ATCC 22019 for anticandidal activity tests. The microorganisms were provided by the Department of Clinical Microbiology, Faculty of Medicine, Karadeniz Technical University, Trabzon, Turkey.

\section{Disc diffusion assay}

The assay was performed by following the protocols of Clinical and Laboratory Standards Institute (2013) and The European Committee on Antimicrobial Susceptibility Testing (2014). Briefly, Methanol was used as a solvent for the extracts of dried plant and final concentration $(30 \mathrm{mg}$ $\mathrm{ml}^{-1}$ ) was sterilized by filtration through a $0.45 \mu \mathrm{m}$ Millipore filter. Antimicrobial tests were then performed by the disc diffusion method using $100 \mu \mathrm{L}$ of suspension containing $1 \mathrm{x}$ $10^{8} \mathrm{CFU} / \mathrm{mL}$ bacteria, $1 \times 10^{6} \mathrm{CFU} / \mathrm{mL}$ yeast spread on nutrient agar (NA), sabouraud dextrose agar (SDA) or potato dextrose agar (PDA) medium respectively. The discs with a $6 \mathrm{~mm}$ diameter were impregnated with $30 \mathrm{mg} \mathrm{ml}^{-1}$ extract (300 $\mu \mathrm{g}$ per disc) placed on the inoculated agar. Methanol again was used for preparing negative controls. For positive reference standards, ofloxacin (10 $\mu \mathrm{g}$ per disc), 
sulbactam $(30 \mu \mathrm{g})+$ cefoperazona $(75 \mu \mathrm{g}) ;(105 \mu \mathrm{g}$ per disc $)$ and/or netilmicin (30 $\mu \mathrm{g}$ per disc) were used to determine the sensitivity of each strain of microbial species tested. The inoculated plates were incubated at $37^{\circ} \mathrm{C}$ for $24 \mathrm{~h}$ for clinical bacterial strains, $48 \mathrm{~h}$ for yeasts. Antimicrobial activity was assessed by measuring the inhibition zone against the test organisms. In this experiment, all assays were repeated twice.

\section{Microdilution assay}

Minimum inhibitory concentration (MIC) values were decided for the bacterial strains which were sensitive to the extracts in the disc diffusion assay. Inocula of the bacterial strains were prepared from $12 \mathrm{~h}$ broth cultures, and suspensions were adjusted to $0.5 \mathrm{McF}$ arland standard turbidity. The extracts dissolved in $10 \%$ dimethylsulphoxide (DMSO), were first diluted to the 500 $\mu \mathrm{g} / \mathrm{mL}$ highest concentration to be tested, then serial two fold dilutions were performed in order to get a concentration range from 7.8 to $250 \mu \mathrm{g} / \mathrm{mL}$ in $10 \mathrm{~mL}$ sterile test tubes supplemented with nutrient broth. MIC values of the extracts against bacterial strains were decided by the broth microdilution method (Clinical and Laboratory Standards Institute). Firstly, $100 \mu \mathrm{L}$ of Mueller Hinton Broth (MHB) was dispensed in each of the 96-well plates. Then, the $100 \mu \mathrm{L}$ aliquot from the prepared stock solution with a concentration of $500 \mu \mathrm{g} / \mathrm{mL}$ was added to the first well and thoroughly mixed. Following this, serial dilutions were done by transferring $100 \mu \mathrm{L}$ aliquots from the first well to the last well. A dilution of $1 / 10$ bacterial suspension was prepared from $1 \times 10^{8} \mathrm{CFU} / \mathrm{mL}$ bacteria and then $5 \mu \mathrm{L}$ was added to each well from this dilution to make final concentration $5 \times 10^{5} \mathrm{CFU} / \mathrm{mL}$ per well. Among the two last columns of the plate, one was used for sterility control without bacteria. Another column was used for growth control without test compound. Microbial growth was detected by reading the respective absorbance (Abs) at 600 nm using an ELx 800 universal microplate reader (Biotek Instrument Inc, Highland Park, VT, USA) in each medium and confirmed by plating $5 \mu \mathrm{L}$ samples from clear wells on nutrient agar medium. The tested extracts were screened twice against each organism in this study. The MIC value was defined as the lowest concentration required inhibiting the growth of micro-organisms.

\section{Cytotoxic activity assay}

\section{Cell culture}

Eagle's Minimum Essential Medium (EMEM) was used basal medium and human HeLa cervical carcinoma cells were cultured in EMEM containing 10\% (v/v) heatinactivated fetal bovine serum, and antibiotic-antimycotic mixture [penicillin $(100 \mathrm{U} / \mathrm{mL})$, streptomycin (100 $\mu \mathrm{g} / \mathrm{mL})$, amphotericin B $(0.25 \mu \mathrm{g} / \mathrm{mL})] .1 \times 10^{5}$ cells $/ \mathrm{mL}$ concentration and maintained at $37{ }^{\circ} \mathrm{C}$ in an atmosphere with $5 \% \mathrm{CO}_{2}$ were used to seed cells. The samples were added to the basal growth medium, after dissolving in EMEM.

Cytotoxicity test (MTT viability assay)

MTT assay was used to cytotoxic activities of the $\mathrm{MeOH}$ extracts with some minor modifications (Önay-
Uçar et al., 2012). The assay based on the reduction of MTT (3- (4, 5- dimethylthiazol -2 -yl) -2, 5diphenyltetrazolium bromide) to a colored formazan product by mitochondrial dehydrogenase, which is active only in living cells (Mosmann, 1983). The stock solutions of the samples were diluted with EMEM. The cells were maintained in 96 well-plates (each well contained $200 \mu \mathrm{L}$ cell suspension at a density of $1 \times 10^{5}$ cells $/ \mathrm{mL}$ ). After reaching confluence ( 1 day later), the cells were treated with increasing concentrations $(1 \mu \mathrm{g} / \mathrm{mL}-1000 \mu \mathrm{g} / \mathrm{mL})$ of the samples diluted with EMEM. After growth of the cells for $48 \mathrm{~h}$ at $37{ }^{\circ} \mathrm{C}$ in a humidified $5 \% \mathrm{CO}_{2}$ atmosphere, the adherent cells were washed with phosphate buffered saline (PBS), then $10 \mu \mathrm{L}$ of MTT stock solution $\left(5 \mathrm{mg} \mathrm{ml}^{-1}\right)$ and $90 \mu \mathrm{L}$ PBS buffer was added to each well and the plates were further incubated at $37^{\circ} \mathrm{C}$ for $4 \mathrm{~h}$. At the end of this period, supernatants were separated, DMSO $(200 \mu \mathrm{L})$ was added to each well to solubilize the water-insoluble purple formazan crystals. The absorbance was measured at 570 and $690 \mathrm{~nm}$ in a microplate reader ( $\mu$ Quant, Bio-Tek Instruments, Inc. Highland Park, USA). The cell viability was calculated using the following equation:

Cell viability $(\%)=($ A sample $/ \mathrm{A}$ control $) \times 100$

Absorbance of the experimental group was A sample meanwhile absorbance of the control group was A control. The half maximal inhibitory concentration $\left(\mathrm{IC}_{50}\right)$ of the extracts on HeLa cells were calculated from a graph of cell viability versus the sample concentrations.

\section{HPLC analysis of phenolic compounds}

HPLC-PDA analysis of biomass methanol extract was performed according to a previously described method (Kim et al., 2006; Ma et al., 2009). The HPLC-PDA system (ELITE LaChrome, Hitachi) composed of quaternary pumps (L-2130 model), an auto injector (model L-2200), connected to a photo diode array (L-2455 Model). A C-18 reverse phase column $(250 \mathrm{~mm} \times 4.6 \mathrm{~mm}$ id, $5 \mu \mathrm{m}$ particle size, Agilent USA) was used for the analysis which was fixed in a column oven (Model-2300). The mobile phase was a mixture of solvent $\mathrm{A}(2 \%$ acetic acid $(\mathrm{AcOH})$ in water $)$ and solvent B (70:30, acetonitrile/water) that was sonicated before staring and sustained degassed by built in HPLC system. Volume of the injection was $20 \mu \mathrm{L}$ and column was maintained at $30^{\circ} \mathrm{C}$. The flow rate was maintained stable at $1 \mathrm{~mL} / \mathrm{min}$ using gradient programming. Starting the flow of mobile phase as B (5\%) to three minutes, gradual increase (up-to 15, 20, 25, 40 and $80 \%$ at 8, 10, 18, 25 and 35 minutes respectively) and drop back to $5 \%$ at $40 \mathrm{~min}$ and left for $10 \mathrm{~min}$ to equilibrate in column. Eluent was permanently monitored through PDA by measuring at three different wavelengths; 280, 315 and $350 \mathrm{~nm}$.

\section{Statistical analysis}

One-way analysis of variance (ANOVA) module of GraphPad Prism 5 was used statistical comparisons for the cytotoxicity test. All differences in mean values were evaluated significant at $\mathrm{P}<0.05$. Data are given as mean values $\pm S D$ with ' $n$ ' denoting the number of experiments. Another each data were statistically assessed using analysis of variance (ANOVA) with SPSS (version 23.0) software. Statistical significance, and the mean \pm SD (standard 
1148

deviation) was calculated using analysis of variance (ANOVA) and Duncan's multiple range test (DMRT) respectively. The statistical significance of differences between treatments was considered significant at $\mathrm{P}<0.05$. Sixteen explants were evaluated for each replicate and all experiment was repeated as triplicates for a definite results.

\section{Results and Discussion}

\section{Seed germination}

Surface sterilized seeds of $C$. sylvatica were successfully germinated for 30 days. Among the basal media tested, full strength (FS) MS containing $1.0 \mathrm{mg} \mathrm{l}^{-1} 6$-BA was the most effective, with $94.44 \pm 1.93 \%$ germination percentage together with half strength (HS) MS, followed by HS of B5 $(91.11 \pm 1.92 \%)$ and FS of B5 (90 $\pm 3.33 \%)$. Statistical analysis also showed significant differences between $\mathrm{HS}$ and FS of MS and B5 media in terms of the germinating seed number $(\mathrm{P}<0.05)$, although the highest shoot length was obtained from cytokinin free medium of B5 (Fig. 1). However, the latter was not used for shoot proliferation as leading to produce proliferation of weaker shoots and lower fresh and dry weight efficiencies compared to the other basal media. Based on these results, full strength MS medium can be used in continuing shoot proliferation.

\section{Shoot proliferation}

In terms of shoot proliferation, MS medium containing $2.0 \mathrm{mg} \mathrm{l}^{-1} 6-\mathrm{BA}$ and $0.1 \mathrm{mg} \mathrm{l}^{-1}$, IBA was found to be more effective than all PGRs tested regarding the number of shoots and biomass, whereas $2.0 \mathrm{mg} \mathrm{l}^{-1} \mathrm{KIN}$ combined with $0.1 \mathrm{mg} \mathrm{l}^{-1}$ IBA was more effective than 6-BA, TDZ and $2 \mathrm{iP}$ when shoot length and node numbers per explant were taken into account. The highest shoot number ( $4.42 \pm 0.35$ shoots per explant) was obtained from the application of 6BA, followed by TDZ (3.17 \pm 0.58 shoots), KIN (2.90 \pm 0.49 shoots $)$ and $2 \mathrm{iP}(2.65 \pm 0.49$ shoots $)$ per explant (Table1). On the other hand, KIN produced the higher average shoot length $(38.97 \pm 2.85 \mathrm{~mm})$ with the higher average of node number ( $4.37 \pm 0.43$ nodes per explant), TDZ produced the lowest average of shoot length (18.90 \pm $1.64 \mathrm{~mm}$ ) with the lowest average of node number $(2.89 \pm$ 0.63 nodes per explant) (Table 1). Statistical analysis showed significant differences between KIN and other applied cytokinins in terms of the shoot length and node numbers $(\mathrm{P}<0.05)$. In addition, when biomass yield was in question, 6-BA gave the highest fresh weight $(0.28 \pm 0.02 \mathrm{~g}$ per explant $)$ and dry weight $(0.0235 \pm 0.0037$ g per explant $)$ (Table 1). 6-BA was showed a statistically significant difference from other cytokinins applied based on the shoot number, fresh and dry weight per explant parameters $(\mathrm{P}<$ 0.05). As a result, the type of cytokinin employed greatly influenced the shoot proliferation for C. sylvatica (Fig. 2). The use of secondary metabolites has gained an increasing momentum in the medical field in recent years. Consequently, the new plant breeding technologies are used for increasing the yield of these valuable products. Although many researchers have studied Lamiaceae members for the determination of secondary metabolite contents naturally (Ziaková and Brandšteterová, 2003; Proestos et al., 2005; Araniti et al., 2013) there have been few reports regarding the use of in vitro tissue culture methods for the generation of these metabolites (Arikat et al., 2004; Oluk and Çakır, 2009; Pistelli et al., 2013). As reported elsewhere, higher rosmarinic acid sources rather than $C$. sylvatica are vast in literature, the present study shows that micropropagation is more convenient, safe, and has a potential for the optimization of high yield culture lines that selectively produce any particular phenolics. As far as micropropagation studies are concerned, MS medium supplemented with 6-BA showed promoted the shoot multiplication of some species (Scarpa et al., 2000; Avato et al., 2005; Ruffoni and Mascarello, 2009; Pistelli et al., 2013) Although in one case, Pistelli et al. (2013), obtained the highest rate of shoot length in MS medium supplemented with 6-BA, KIN was proven to be the most powerful basal medium for shoot length in our experiments. In terms of highest multiple shoot formation, our findings in accordance with the previous report published elsewhere (Grigoriadou and Maloupa, 2008).

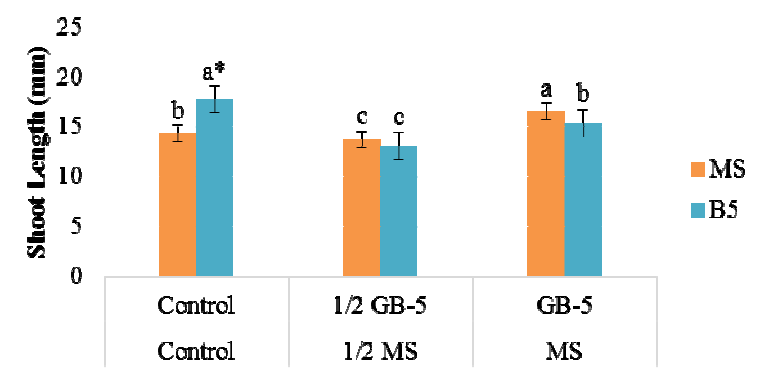

Fig. 1. Effect of different media on germination of $C$. sylvatica seeds. Data obtained from 4 week-old cultures and represent a total of three replicates of 30 seeds per treatment. Bars represent S.E. according to Duncan's multiple range test $(\mathrm{P}<$ $0.05){ }^{*}$ show the highest shoot length value between media for 30 days

Table 1. Effects of different PGRs in the presence of IBA $\left(0.1 \mathrm{mg} \mathrm{l}^{-1}\right)$ on the shoot number, shoot length and node number, fresh and dry weight of $C$. sylvatica

\begin{tabular}{|c|c|c|c|c|c|}
\hline $\begin{array}{c}\text { PGRs } \\
\left(2.0 \mathrm{mgl}^{-1}\right)\end{array}$ & $\begin{array}{c}\text { Shoot } \\
\text { Number/ } \\
\text { Explant }\end{array}$ & $\begin{array}{l}\text { Shoot } \\
\text { Length } \\
(\mathrm{mm})\end{array}$ & $\begin{array}{c}\text { Node } \\
\text { Number/ } \\
\text { Explant }\end{array}$ & $\begin{array}{c}\text { Fresh } \\
\text { Weight } \\
\text { (g) }\end{array}$ & $\begin{array}{c}\text { Dry } \\
\text { Weight } \\
\text { (g) }\end{array}$ \\
\hline 6-BA & $4.42^{a} \pm 0.35 a$ & $29.33 \pm 2.36 c$ & $3.98 \pm 0.55 b$ & $0.283 \pm 0.028 \mathrm{a}$ & $0.024 \pm 0.004 a$ \\
\hline KINETIN & $2.89 \pm 0.49 \mathrm{bc}$ & $38.97 \pm 2.85 \mathrm{a}$ & $4.37 \pm 0.43 \mathrm{a}$ & $0.118 \pm 0.028 \mathrm{c}$ & $0.015 \pm 0.002 b$ \\
\hline $2 \mathrm{iP}$ & $2.65 \pm 0.49 c$ & $35.05 \pm 2.62 b$ & $4.29 \pm 0.46 \mathrm{ab}$ & $0.124 \pm 0.035 c$ & $0.013 \pm 0.002 b c$ \\
\hline TDZ & $3.16 \pm 0.58 b$ & $18.91 \pm 1.63 \mathrm{~d}$ & $2.89 \pm 0.62 \mathrm{c}$ & $0.246 \pm 0.029 b$ & $0.016 \pm 0.003 b$ \\
\hline
\end{tabular}

Data recorded on the 4 weeks after the culture and a total of three replicates of 16 plants per treatment for shoot regeneration.

Values having the same letter( $(s)$ in the same line are not significantly different according to Duncan's multiple range test at $\mathrm{P}<0.05$ 


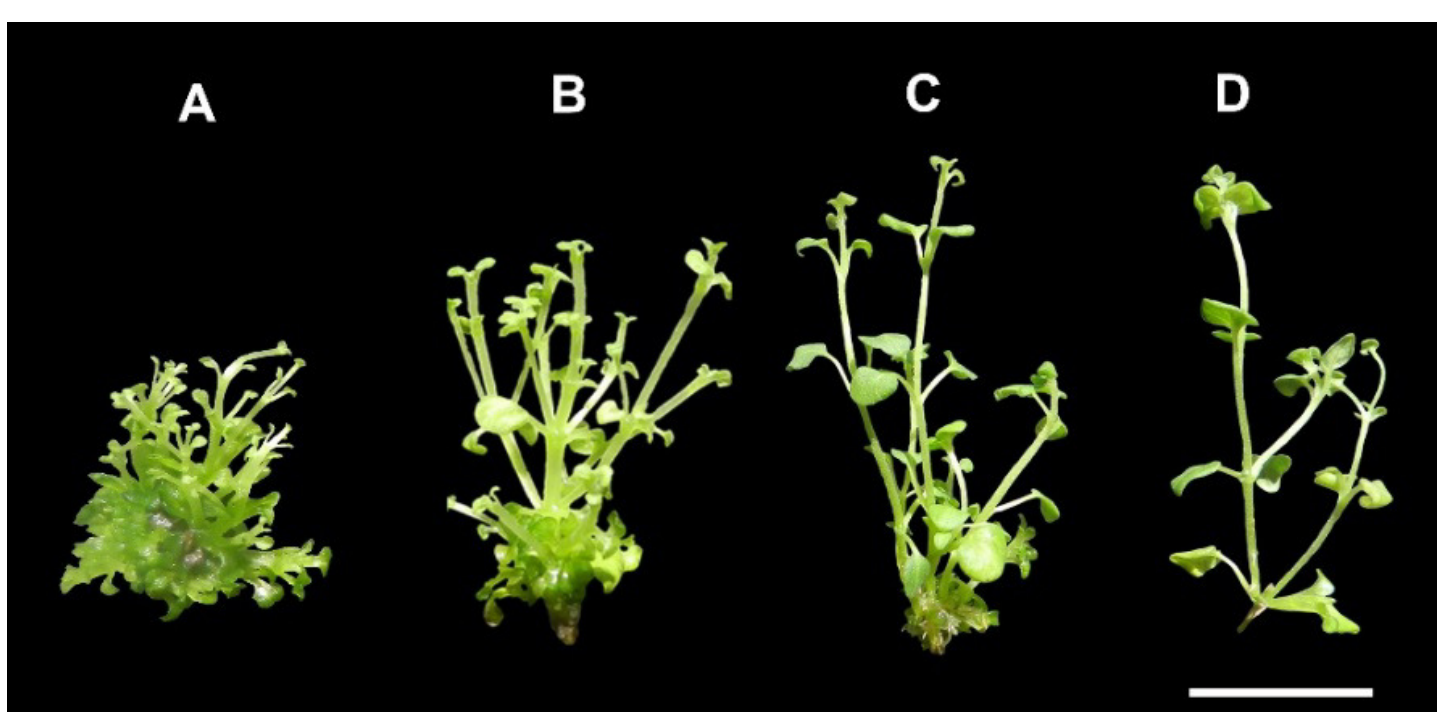

Fig. 2. In vitro propagation of Calamintha sylvatica. Shoot proliferation after 4 weeks; (A) on culture medium from nodal explant on MS medium supplemented with 2.0/0.1 mg/L TDZ/IBA. (B) with 2.0/0.1 mg/L 6-BA/IBA. (C) with 2.0/0.1 mg/L 2iP/IBA. (D) with $2.0 / 0.1 \mathrm{mg} / \mathrm{L}$ KIN/IBA. Bar $=1.65 \mathrm{~cm}$

\section{Antimicrobial activity}

Amongst all microorganisms selected, only $S$. aureus ATCC 25923 were found to be sensitive against the extracts of natural and micropropagated seedlings with MIC values at 6.25 and $3.33 \mathrm{mg} \mathrm{ml}^{-1}$, respectively. It could be concluded that extracts obtained from both natural and micropropagated seedlings had weak antimicrobial activities.

\section{Cytotoxic activity}

TT assay was assessed to determine cytotoxic activity of the samples on HeLa cell line. Data of the cytotoxic activity results was presented as mean percentages of control $\pm S D$ and linear modelling regression analysis was used to calculate the $\mathrm{IC}_{50}$ values. As illustrated in Fig. 3, natural and micropropagated C. sylvatica extracts exhibited cytotoxic activity against the HeLa cells. Cytotoxic activity of natural $C$. sylvatica extract was higher than micropropagated $C$. sylvatica extract, the half maximal inhibitory concentration ( $\mathrm{IC}_{50}$ ) of the samples were obtained with $83 \mu \mathrm{g} / \mathrm{mL}$ and 98 $\mu \mathrm{g} / \mathrm{mL}$ on $\mathrm{HeLa}$ cells, respectively. At concentrations lower than $25 \mu \mathrm{g} / \mathrm{mL}$ it enhanced the relative viability of the human cell lines HeLa. In the present study, we also examined the cytotoxic effects of $C$. sylvatica extracts on HeLa cells, for the first time. The results showed that $C$. sylvatica $\mathrm{MeOH}$ extracts exhibited cytotoxic activity against the HeLa cells. While $\mathrm{IC}_{50}$ value of natural extract was 83 $\mu \mathrm{g} / \mathrm{mL}, \quad \mathrm{IC}_{50}$ value of micropropagated extract was 98 $\mu \mathrm{g} / \mathrm{mL}$. Mohanty and coworkers studied the cytotoxic effects of natural and micropropagated Leptadenia reticulata extracts against different cancer cell line. They were found that micropropagated plant extract showed almost similar cytotoxic properties to that of naturally grown plant extract (Mohanty et al., 2014). Our results are similar with their results.

\section{Phenolic contents}

Since the effects of in vitro culture conditions, particularly the impacts of different cytokinins on phenolic contents of this species were not investigated before; it would be noteworthy to study that whether a considerable change in the phenolic contents is available or not when compared by comparing natural and in vitro biomass. Accordingly, HPLC chromatograms of the phenolic standards at $280 \mathrm{~nm}$ were given in Fig. 4. Based on these data, the content of rosmarinic acid was found to be surprisingly higher in all in vitro tissue culture obtained biomass than those of natural sample where it was present in trace amounts. Particularly, the micropropagated seedlings contained only rosmarinic acid, denoting the selective biosynthesis of this phenolic acid (Fig. 5). Some phenolics were found in trace amounts while the others were in high that could not be identified (Fig. 6). Micropropagation has already been assumed safe and economic way to grow beneficial plant species without seasonal constraint and make it possible to have plant species with desired compounds in higher quantity. In the present study, increased quantity of rosmarinic acid in micropropagated plantlets such as $2 \mathrm{iP}$ samples and selective synthesis in seed germination demonstrated the potential of using the in vitro biosynthesis of this important natural antioxidant. Some additional peaks in samples (apart from seed germination) could not be identified due to scarcity of phenolic standard. However, these were not identified as any of the phenolic standard used in the study whereas the UV spectra of unidentified peaks were given in Fig. for author's interest (Fig. 6). In a recent report Boonyarikpunchai et al. (2014) presents the bio-medicinal species Thunbergia laurifolia Lindl. as source of rosmarinic acid producing 0.0261 and $0.235 \%$ on percent dry weight basis and extract basis, respectively. Whereas a proceeding report, was based on the study of biotechnological production of rosmarinic acid via Dracocephalum kotschyi Boiss. hairy root cultures, was found to be a source producing the natural antioxidant from 0.001 to $0.15 \%$ on dry weight basis (Fattahi et al., 2013). Our results indicated that micropropagated $C$. sylvatica produced higher rosmarinic acid than former of the above 
1150

reported sources while relatively lower in some cases of later studied sources. However, advantage over later case was the production of selective rosmarinic acid in direct seed germination and in vitro culturing. In conclusion this is the first report on multiplication of shoots via
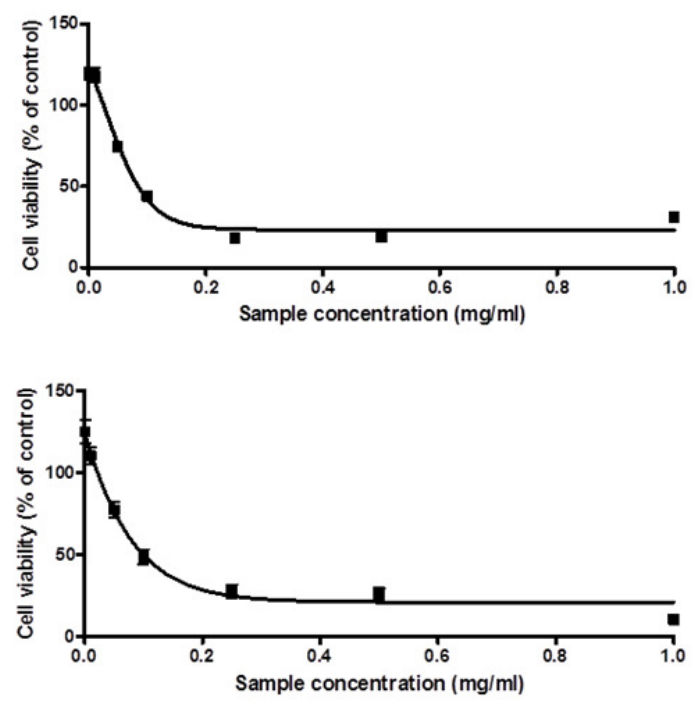

Fig. 3. Cytotoxic effect of natural (A) and micropropagated (B) Calamintha sylvatica extracts on HeLa cells. Experiments were performed in triplicate. The vertical bars on the points on the graph show standard deviation values. The consistency between groups was determined by one-way analysis of variance $\left(P<0.0001, R^{2}=0.969\right.$ and $P<0.0001, R^{2}=0.920$, respectively) micropropagation method. C. sylvatica showed high micropropagation performance and produced remarkable amount of rosmarinic acid in vitro as well as antimicrobial and cytotoxic effect.

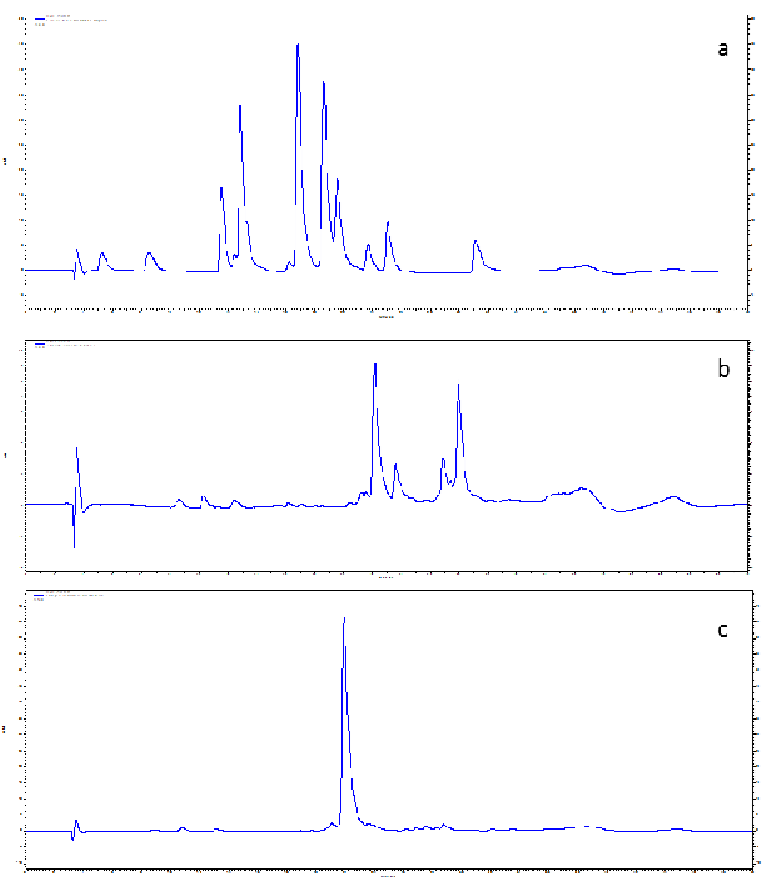

Fig. 4. (A) HPLC chromatograms of the phenolic standards at 280 nm. Peak identification: (1) gallic acid, (2) protocatechuic acid, (3) p-Hydroxy benzoic acid, (4) catechin, (5) chlorogenic acid, (6) caffeic acid, (7) vanillic acid, (8) syringic acid, (9) epicatechin, (10) rutin, (11) ferulic acid, (12) o-coumaric acid, (13) benzoic acid, (14) Rosamarinic Acid, (15) Quercetin. (B) Natural C. sylvatica Sample and (C) Samples from seedlings obtained from direct seed germination

\section{$\mathrm{mg} / 100 \mathrm{~g}$}

100,00

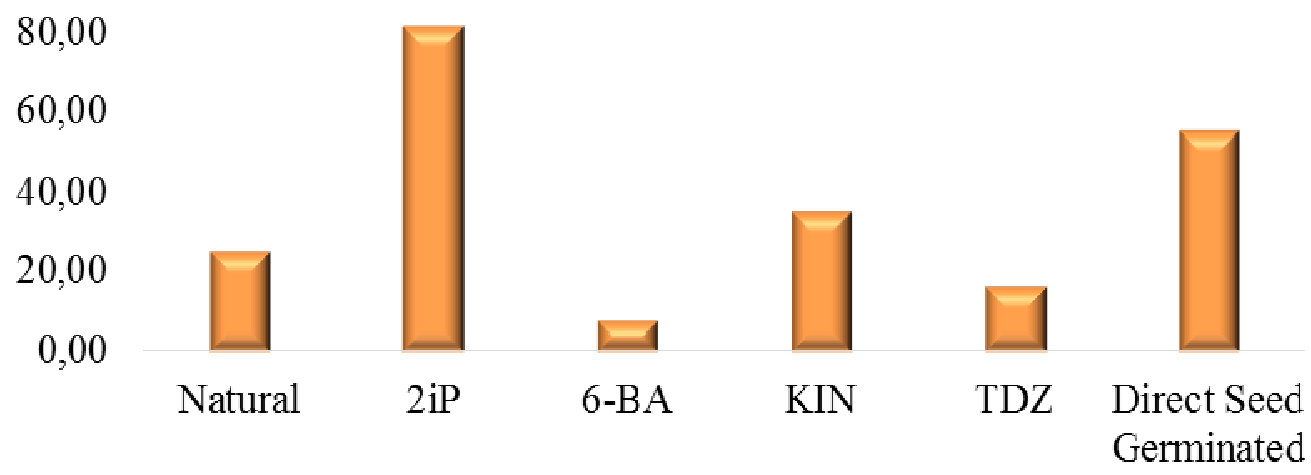

Fig. 5. Rosmarinic acid content $(\mathrm{mg} / 100 \mathrm{~g})$ in natural as well as tissue culture generated biomasses of $C$. sylvatica with the presence of different cytokinins 

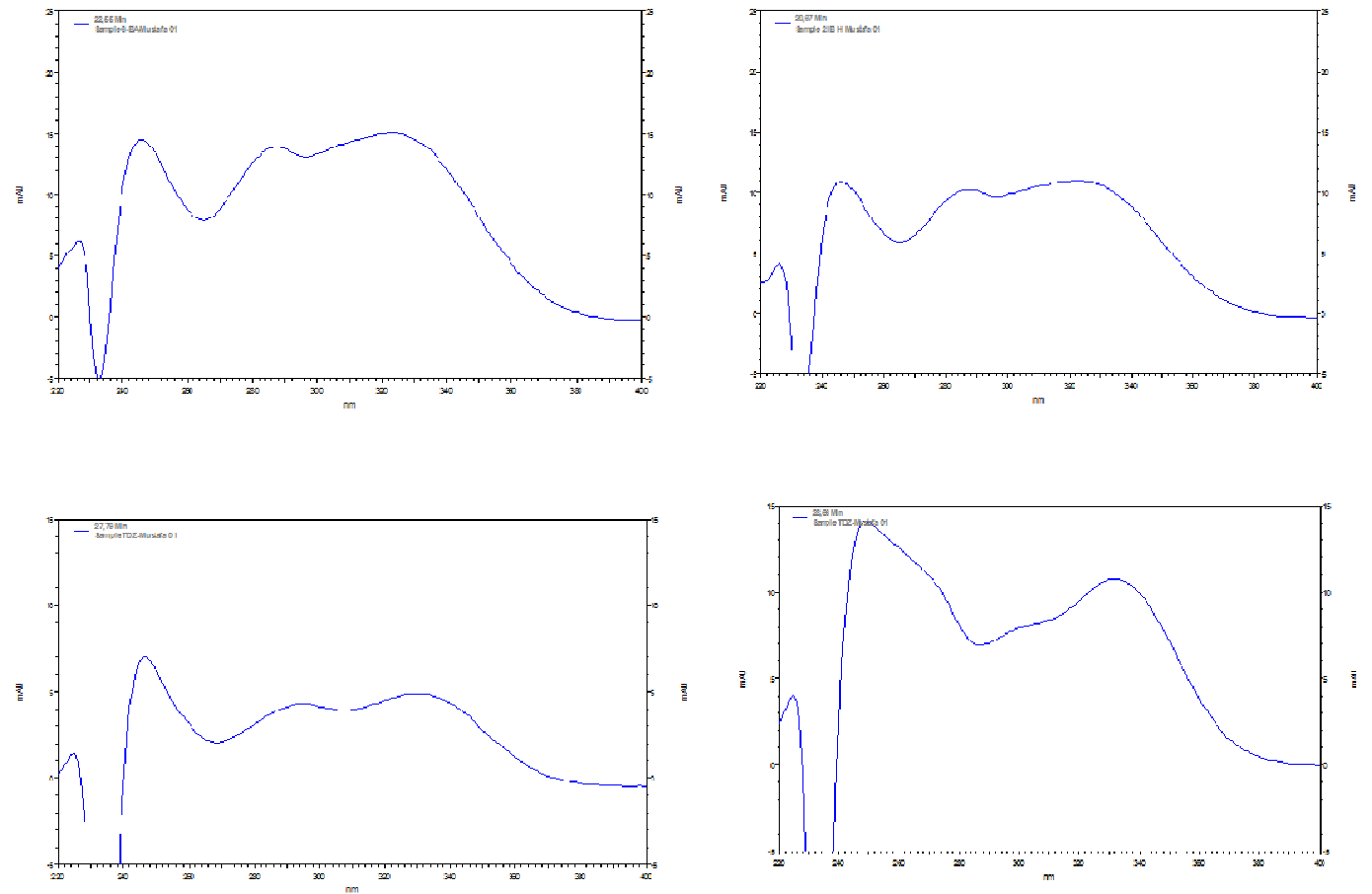

Fig. 6. The UV spectra of some unknown peaks which were showing the evidence of some unidentified phenolics in considerable quantities in vitro tissue culture generated biomass

\section{Conclusions}

In conclusion this is the first report on multiplication of shoots via micropropagation method. C. sylvatica showed high micropropagation performance and produced remarkable amount of rosmarinic acid in vitro as well as antimicrobial and cytotoxic effect.

\section{Acknowledgements}

The study was carried out with the financial support of KTU-BAP (The Scientific Research Commitee of Karadeniz Technical University, Project No. KTUBAP.1064). Authors are thankful to King Saud University for financial support under the issue of Distinguished Scientist Research Fellowship Program (DSFP).

\section{Conflict of Interest}

The authors declare that there are no conflicts of interest related to this article.

\section{References}

Alan S, Kürkçüoğlu M, Ozek T, Can Başer KH (2009). Composition of the essential oils of Calamintha tauricola P.H. Davis. Journal of Essential Oil Research 21(2):143-145.

Araniti F, Lupini A, Mercati F, Statti G, Abenavoli M (2013). Calamintha nepeta L. (Savi) as source of phytotoxic compounds: bio-guided fractionation in identifying biological active molecules. Acta Physiologiae Plantarum 35(6):1979-1988.

Arikat NA, Jawad FM, Karam NS, Shibli RA (2004). Micropropagation and accumulation of essential oils in wild sage (Salvia fruticosa Mill.). ScientiaHorticulturae-Amsterdam 100(1-4):193-202.

Astani A, Reichling J, Schnitzler P (2012). Melissa officinalis extract inhibits attachment of herpes simplex virus in vitro. Chemotherapy 58(1):70-77.

Avato P, Fortunato IM, Ruta C, D'Eli R (2005). Glandular hairs and essential oils in micropropagated plants of Salvia officinalis L. Plant Science 169(1):29-36.

Baytop A (1983). Farmasötik botanic. İstanbul Üniversitesi Eczacllk Fakültesi Yayınlan 36:282-285 [Pharmaceutical botanic. Istanbul University Faculty of Pharmacy Publications 36:282-285].

Baytop A (1997). Türkçe Bitki Adları Sözlügü. Atatürk Kültür, Dil ve Tarih Yüksek Kurumu. Türk Dili Kurumu Yayınları, 578, Ankara pp 512 [Turkish Plant Names Dictionary. Atatürk Culture, Language and History Supreme Council. Turkish Language Institution Publications, 578, Ankara pp 512].

Baytop T (1999). Türkiye'de Bitkilerle Tedavi. İstanbul Üniversitesiyayınları No. 3255, Eczacllk Fakültesi yayınları No. 40, İstanbul pp 304371 [Treatment with plant in Turkey. Istanbul University publications No. No. 3255, Faculty of Pharmacy publications Nos. 40, Istanbul pp 304 371].

Boonyarikpunchai W, Sukrong S, Towiwat P (2014). Antinociceptive and anti-inflammatory effects of rosmarinic acid isolated from Thunbergia laurifolia Lindl. Pharmacology Biochemistry and Behavior 124:67-73.

Bown D (1995). The Royal Horticultural Society Encyclopedia of Herbs and Their Uses. Dorling Kindersley, New Yorkpp 97-252.

Clinical and Laboratory Standards Institute (2013). Performance standards for antimicrobial susceptibility testing; twenty-third informational supplements. CLSI document M100-S23, Wayne, PA/USA.

Cunningham $A B$ (1993). African medicinal plants: setting priorities at the interface between conservation and primary health care. People and Plants working paper I. Paris. UNESCO.

Cüce M, Bekircan T, Laghari AH, Sökmen M, Sökmen A, Uçar EÖ, Kullç AO (2017). Antioxidant phenolic constituents, antimicrobial and cytotoxic properties of Stachys annua L from both natural resources and 
1152

micropropagated plantlets. Indian Journal of Traditional Knowledge 16(3):407-413.

De Silva T (1997). Industrial utilization of medicinal plants in developing countries. In: Bodeder G, Bhat KKS, Burley J, Vantomme P (Eds). Medicinal plants forest conservation and healthcare. Non-Wood Forest Products No 11, FAO, Rome, Italy.

Debnath M, Malik C, Bisen P (2006). Micropropagation: a tool for the production of high quality plant-based medicines. Current Pharmaceutical Biotechnology 7(1):33-49.

Dobravalskytė D, Venskutonis PR, Talou T (2012). Antioxidant properties and essential oil composition of Calamintha grandiflora L. Food Chemistry 135(3):1539-1546.

Döring AS, Petersen M (2014). Production of caffeic, chlorogenic and rosmarinic acids in plants and suspension cultures of Glechoma hederacea. Phytochemistry Letters 10:111-117.

European Committee on Antimicrobial Susceptibility Testing (2014). EUCAST disk diffusion test manual, version 4.0. Retrieved 2016 November 12 from http://www.eucast.org/ast_of_bacteria/disk diffusion_methodology/.

Fattahi M, Nazeri V, Torras-Claveria L, Sefidkon F, Cusido RM,ZamaniZ, Palazon J (2013). A new biotechnological source of rosmarinic acid and surface flavonoids: Hairy root cultures of Dracocephalum kotschyi Boiss. Industrial Crops and Products 50:256-263.

Formisanoa C, Olivieroa F, Riganoa D, Saabb AM, Senatorea F (2014). Chemical composition of essential oils and in vitro antioxidant properties of extracts and essential oils of Calamintha origanifolia and Micromeria myrtifolia, two Lamiaceae from the Lebanon flora. Industrial Crops and Products 62:405-411.

Gamborg OL, Miller RA, Ojima K (1968). Nutrient requirements of suspension cultures of soybean root cells. Experimental Cell Research 50(1):151-158.

Grigoriadou K, Maloupa E (2008). Micropropagation and salt tolerance of in vitro grown Crithmum maritimum L. Plant Cell, Tissue and Organ Culture 94(2):209-217.

Kim K-H, Tsao R, Yang R, Cui SW (2006). Phenolic acid profiles and antioxidant activities of wheat bran extracts and the effect of hydrolysis conditions. Food Chemistry 95(3):466-473.

Louvel S, Moodley N, Seibert I, Steenkamp P, Nthambeleni R, Vidal V, ... Klimkait T (2013). Identification of compounds from the plant species Alepidea amatymbica active against HIV. South African Journal of Botany 86:9-14.

Lucchesini M, Mensuali-Sodi A (2010). Plant tissue culture - An opportunity for the production of nutraceuticals. Advances in Experimental Medicine and Biology 698:185-202.

Luis JC, González-Padrón MY, Pérez RM, Viera IF, González FV (2013). Rosmarinic acid: biological, pharmological and in vitro plant cell culture approximation. In: Brahmachari $\mathrm{G}(\mathrm{Ed})$. Chemistry and pharmacology of naturally occurringbioactive compounds, CRC Press, pp 471-482.

Ma Y-Q, Chen J-C, Liu D-H, Ye X-Q (2009). Simultaneous extraction of phenolic compounds of citrus peel extracts: Effect of ultrasound. Ultrasonics Sonochemistry 16(1):57-62.

MalikRA, Gupta RC, Singh V,BalaS, KumariS (2016). New chromosome reports in Lamiaceae of Kashmir (Northwest Himalaya), India.
Protoplasma 254(2):971-985.

Mohanty SK, Malappa K, Godavarthi A, Subbanarasiman B, Maniyam A (2014). Evaluation of antioxidant, in vitro cytotoxicity of micropropagated and naturally grown plants of Leptadenia reticulate (Retz.) Wight \& Arn.-an endangered medicinal plant. Asian Pacific Journal of Tropical Medicine 7:S267-S271.

Mosmann T (1983). Rapid colorimetric assay for cellular growth and survival: Application to proliferation and cytotoxicity assays. Journal of Immunological Methods 65(1-2):55-63.

Murashige T, Skoog F (1962). A revised medium for rapid growth and bio assays with tobacco tissue cultures. Physiologia Plantarum 15(3)473497.

Oluk EA, Çakır A (2009). Micropropagation of Origanum sipyleum L., an endemic medicinal herb of Turkey. African Journal of Biotechnology 8(21):5769-5772.

Önay-UçarE,Erol Ö, Kandemir B, MertoğluE, Karagöz A, ArdaN (2012). Viscum album L. extracts protects HeLa cells against nuclear and mitochondrial DNA damage. Evidence-Based Complementary and Alternative Medicine 958740.

Parnham MJ, Kesselring K(1985). Rosmarinic acid. Drugs Future 10:756757.

Pistelli L, Giovannini A, Ruffoni B, Bertoli A, Pistelli L (2010). Hairy root cultures for secondary metabolites production. In: Bio-Farms for Nutraceuticals. Springer, Boston, MApp 167-184.

Pistelli L, Noccioli C, D'Angiolillo F, Pistelli L (2013). Composition of volatile in micropropagated and field grown aromatic plants from Tuscany Islands. Acta Biochimica Polonica 60(1):43-50.

Proestos C, Chorianopoulos N, Nychas GJE, Komaitis M (2005). RPHPLC analysis of the phenolic compounds of plant extracts. Investigation of their antioxidant capacity and antimicrobial activity. Journal of Agricultural and Food Chemistry 53(4):1190-1195.

Ruffoni B, Mascarello C (2009). Tecniche per la propagazione in vitro degli arbusti mediterranei. Flortecnica 6:51-52.

Ruffoni B, Pistelli L, Bertoli A, Pistelli L (2010). Plant cell cultures: bioreactors for industrial production. Advances in Experimental Medicine and Biology 698:203-221.

Scarpa G, Milia M, Satta M (2000). The influence of growth regulators on proliferation and rooting of in vitro propagated myrtle. Plant Cell, Tissue and Organ Culture 62(3):175-179.

WüstZibetti A, Aydi A, Arauco Livia M, Bolzan A, Barth D (2013). Solvent extraction and purification of rosmarinic acid from supercritical fluid extraction fractionation waste: economic evaluation and scale-up. Journal of Supercritical Fluids 83:133-145.

Zhu F, Asada T, Sato A, Koi Y, Nishiwaki H, Tamura H (2014). Rosmarinic acid extract for antioxidant, antiallergic, and $\alpha$-Glucosidase inhibitory activities, isolated by supramolecular technique and solvent extraction from Perilla leaves. Journal of Agricultural and Food Chemistry 62(4):885-892.

Ziaková A, Brandšteterová E (2003). Validation of HPLC determination of phenolic acids present in some Lamiaceae family plants. Journal of Liquid Chromatography and Related Technologies 26(3):443-453. 